\title{
PENERAPAN METODE INQUIRI DALAM MENINGKATKAN KONSEP BERPIKIR MAHASISWA PADA MATERI BARISAN BILANGAN REAL
}

\author{
Sudarsono* \\ Program Studi Pendidikan Matematika, STKIP Bima \\ *Email korespondensi: sudarsonolanda123@gmail.com
}

\begin{abstract}
ABSTRAK
Penelitian ini bertujuan untuk mengetahui pengaruh penerapan metode inquiri dalam meningkatkan konsep berpikir mahasiswa pada materi Barisan bilangan Real di STKIP Bima. Penelitian ini menggunakan metode inquiri, dimana mahasiswa dibimbing untuk memperoleh pemahaman dan pengetahuan terkait bilangan Real sebagai titik-titik garis bilangan yang panjangnya tak terhingga, bilangan Real ini berbeda dengan bilangan kompleks yang termaksud didalamnya adalah bilangan imajiner. Peneliti melakukan penelitian di STKIP BIMA prodi matematika pada semester IV A-B dengan jumlah total mahasiswa adalah 45 orang. Pengumpulan data untuk variabel bebas menggunakan lembar observasi, sedangkan variabel terikat diperoleh dari hasil tes pemahaman konsep berpikir. Perlakuan tindakan diberikan sebanyak dua siklus dengan hasil penguasaan konsep pada siklus pertama mencapai 82,4 \% dengan siswa yang berhasil belajar tuntas sebanyak 35 orang. Setelah refleksi, siklus kedua kemudian diperoleh penguasaan rata-rata konsep sebesar 88,8\% dengan siswa yang berhasil belajar tuntas sebanyak 39 orang. Perubahan kuantitas dari siklus I ke siklus II terjadi pada tingkat pemahaman dari $82,4 \%$ menjadi $86,8 \%$ atau ada kenaikan tingkat pemahaman sebesar $4,4 \%$. Hasil penelitian ditemukan penerapan metode inquiri dapat meningkatkan pemahaman konsep berpikir mahasiswa pada materi Barisan bilangan real, yaitu pada setiap siklus: siklus I siswa memperoleh ketuntasan 84,4 \% dan pada siklus II siswa dengan ketuntasan 88,8 \%.
\end{abstract}

Kata Kunci: Inquiri, Konsep berpikir, Barisan Bilangan Real

\begin{abstract}
This study tries to understand the method of applying methods to improve students' understanding of the material in the Real Numbers sequence in STKIP Bima. This research uses inquiry method, where students are guided to gain understanding and knowledge related Numbers as infinite number of point lines, real numbers differ from complex numbers which are referred to as imaginary numbers. Researchers conducted research at STKIP BIMA mathematics study program in the fourth semester of A-B with a total number of students of 45 people. Data collection for independent variables using observation sheets, while variables obtained from the results of concept understanding tests. The treatment of the action $\mathrm{gVen}$ was two cycles with the results of mastery of the concept in the first cycle reaching $82.4 \%$ with students who successfully completed learning as many as 35 people. After reflection, the second cycle was then obtained by mastering the average concept of $88.8 \%$ with 39 students completing successful learning. Changes in the number from cycle I to cycle II occurred at the level of understanding from $82.4 \%$ to $86.8 \%$ or there was an increase in the level of understanding of $4.4 \%$. The results of the study found that the application of the method increased
\end{abstract}


students' understanding of the material The real number sequence, namely in each cycle: the first cycle of students obtained $84.4 \%$ completeness and in the second cycle students with $88.8 \%$ completeness.

Keywords: Inquiry, Concept of thinking, Sequence of Real Numbers

\section{PENDAHULUAN}

Dunia pendidikan selalu mengalami perubahan kurikulum setiap periodenya, dimana ini merupakan bentuk upaya dalam meningkatkan mutu pendidikan di indonesia. Dalam setiap GBHN selalu tercantum bahwa peningkatan mutu pendidikan merupakan salah satu prioritas pembangunan dalam bidang pendidikan. Berbagai inovasi program pendidikan yang dilakukan, antara lain adalah penyempurnaan kurikulum, penggadaan buku ajar dan buku referensi, serta berbagai media dan metode yang disediakan untuk mencapai tujuan pendidikan.

Melihat tingginya ekspektasi pemerintah yang tertuang dalam kurikulum, berbanding terbalik dengan realitas nyata yang ada dilapangan sejauh ini, dimana sekolah menengah dan sekolah tinggi-pun masih mengunakan metode lama yang ditengarai dapat menurunkan standar pendidikan. Penelitian ini dilakukan oleh dosen pengampu matakuliah analisis Real yang sudah memahami karakter dari mahasiswa sebagai subyek penelitian tersebut. Sesuai dengan hasil observasi awal pada bulan maret 2018 kegiatan PBM (Proses Belajar Mengajar) yang ditemukan oleh peneliti saat kegiatan pembelajaran berlangsung, peneliti menemukan aktVitas mahasiswa masih dalam lingkup mencatat dan melakukan kegiatan sesuai dengan perintah dosen saja. Sehingga mahasiswa terlihat pasif dalam PBM (Proses Belajar Mengajar) hal ini menyebabkan mahasiswa terbatas pada mendengar, mencatat dan menjawab ketika dosen memberikan pertanyaan dan mahasiswa hanya bekerja atas perintah dosennya saja. Sedangkan, dalam pembelajaran matematika mengharuskan mahasiswa memiliki konsep berpikir yang mendasar, luas dan terstruktur sehingga ini juga tidak sesuai dengan tujuan pendidikan nasional.

Proses belajar mengajar seperti ini tidak mendorong mahasiswa berpikir kritis dan berkreatifitas, hal ini tidak sesuai dengan hakikat pribadi mahasiswa sebagai subjek belajar yang lebih tinggi. Dengan dasar itu pembelajaran mahasiswa harus membangun sendiri pengetahuan mereka melalui keterlibatan aktif dalam proses belajar mengajar, mahasiswa sebagai pusat kegiatan pembelajaran bukan dosen. Apalagi jika dikaitkan dengan era revolusi 
industri 4.0 dimana manusia dituntut berpikir kritis dengan memanfaatkan media dan teknologi terbarukan abad ini.

Dengan melihat fenomena tersebut di atas, maka hasil belajar atau pemahaman konsep mahasiswa pada realitanya masih rendah dan nilai yang diperoleh mahasiswa rata-rata masih dibawah standar ketuntasan belajar (sumber: hasil wawancara dan dakumentasi). Dengan demikian perlu mengadakan perbaikan dengan menggunakan berbagai metode dan media dalam pembelajaran.

Sebagai alternatif pemecahan dalam masalah ini adalah menerapkan metode inquiri, karena metode inquiri akan mengajak peserta didik untuk berpikir kritis dan ilmiah, dan menuntut peserta didik lebih aktif dalam proses pembelajaran dan bukan sebagai objek melainkan pelaku aktif dalam kegiatan pembelajaran.

Agar lebih memperjelas argumen di atas Mulyasa mengemukakan bahwa metode inquiri adalah metode yang mampu menggiring peserta didik untuk menyadari apa yang telah didapatkan selama belajar. Inquiri menempatkan peserta didik sebagai subyek belajar yang aktif. Sedangkan menurut (Blosser :1990) alasan rasional penggunaan metode inquiri adalah bahwa peserta didik akan mendapatkan pemahaman yang lebih baik mengenai Sains dan akan lebih tertarik terhadap Sains jika mereka dilibatkan secara aktif dalam "melakukan" Sains. Investigasi yang dilakukan oleh mahasiswa merupakan tulang punggung metode inquiri. Investigasi ini difokuskan untuk memahami konsep-konsep berpikir dan meningkatkan keterampilan proses berpikir ilmiah mahasiswa. Diyakini bahwa pemahaman konsep merupakan hasil dari proses berfikir ilmiah tersebut, Lebih lanjut lagi menurut (Sagala:2006) metode inquiri merupakan metode pembelajaran yang berupaya menanamkan dasar-dasar berfikir ilmiah pada diri peserta didik, sehingga dalam proses pembelajaran ini mahasiswa lebih banyak belajar sendiri, mengembangkan kreatVitas dalam memecahkan masalah. mahasiswa benar-benar ditempatkan sebagai subjek yang belajar. Pada penelitian ini peranan dosen dalam pembelajaran dengan metode inquiri adalah sebagai pembimbing dan fasilitator. Tugas dosen yang pertama adalah memilih pokok bahasan yang perlu disampaikan kepada mahasiswa untuk dipecahkan, namun dimungkinkan juga bahwa masalah yang akan dipecahkan dipilih oleh mahasiswa sendiri pula. Kemudian tugas dosen selanjutnya adalah menyediakan sumber belajar bagi mahasiswa dalam rangka memecahkan pokok materi yang 
diberikan. Bimbingan dan pengawasan dosen masih diperlukan, tetapi intervensi terhadap kegiatan mahasiswa dalam pemecahan masalah harus dikurangi (Sagala:2006).

Belajar adalah proses yang ditandai dengan adanya perubahan pada diri seseorang sebagai proses hasil belajar dapat ditunjukkan dalam berbagai bentuk seperti perubahan pengetahuannya, pemahamannya, sikap dan tingkah lakunya, keterampilannya, kecakapan dan kemampuannya, daya reaksinya, daya penerimaannya dan aspek lain yang ada pada indvidu(Sudjana:2004).

Tujuan belajar untuk mengembangkan nilai afeksi memerlukan penciptaan lingkungan yang berbeda dengan yang dibutuhkan untuk tujuan belajar pengembangan gerak. Sedangkan menurut Sudirman (26:2004) Tujuan belajar ada tiga jenis, yaitu: (1) Untuk mendapatkan pengetahuan. Pemilikan pengetahuan dan kemampuan berpikir merupakan hal yang tidak dapat dipisahkan. Dengan kata lain, tidak dapat mengembangkan kemampuan berfikir tanpa bahan pengetahuan, sebaliknya kemampuan berpikir akan memperkaya pengetahuan. (2) Penanaman konsep dan keterampilan. Penanaman konsep atau merumuskan konsep, juga memerlukan suatu keterampilan. Keterampilan dapat dididik dengan banyak melatih kemampuan. Keterampilan ini ada yang bersifat jasmani dan juga yang bersifat rohani. Keterampilan jasmani adalah keterampilan yang dapat dilihat seperti penampilan dari anggota tubuh. Sedangkan pada keterampilan rohani tidak dapat dilihat ujung dan pangkalnya, dan bersifat abstrak, seperti keterampilan berpikir serta kreatifitas untuk menyelesaikan suatu konsep. (3)Pembentukan sikap. Pembentukan sikap mental dan perilaku anak didik, tidak akan terlepas dari soal penanaman nilai, transfer of value.

Ditinjau dari perkembangan ilmu pengetahuan yang semakin maju, pendidik dituntut selalu berkreatifitas dalam menciptakan suasana belajar dengan pembelajaran aktif (actVe learning) serta memilih berbagai metode dan media yang bervariasi, menyenangkan dan dapat menimbulkan gairah belajar peserta didik sehingga mudah memahami setiap konsep pembelajaran yang diajarkan. Salah satu alternatif pemecahan masalah tersebut adalah penerapan metode inquiri.

Berdasarkan latar belakang di atas peneliti ingin menerapkan metode pembelajaran yang efektif untuk digunakan dalam proses belajar mengajar dengan melakukan suatu penelitian tentang "Penerapan Metode Inquiri Dalam Meningkatkan Konsep Berpikir Mahasiswa Pada Materi Barisan Bilangan Real”. 


\section{METODE PENELITIAN}

Konsep penelitian yang akan dilaksanakan sesuai dari latar belakang yang ada dari permasalahan upaya meningkatkan pemahaman konsep berpikir ini, sesuai dengan kriteria jenis penelitian tindakan kelas (PTK), yang dilaksanakan di semester V kelas A-B tahun akademik 2017-2018, dimana merupakan jenis penelitian partisipatif yang berkolaboratif dengan antara peneliti dan dosen pengampu matakuliah. Subyek penerima tindakan penelitian ini adalah mahasiswa kelas A-B dengan jumlah siswa 45 orang terdiri dari 25 mahasiswi dan 20 mahasiswa. Dan objek dalam penelitian ini adalah penerapan metode inquiri dalam meningkatkan pemahaman konsep berpikir, peneliti menggunakan metode inquiri karena metode ini akan membawa mahasiswa untuk lebih aktif, sebab metode inquiri menggiring mahasiswa untuk menemukan sendiri jawaban dari pertanyaan, dan mahasiswa mudah untuk memahami suatu konsep, baik itu dengan cara kreatif maupun dengan cara lain.

\section{HASIL DAN PEMBAHASAN}

Penelitian tindakan kelas ini bertujuan untuk meningkatkan Pemahaman Konsep Berpikir Mahasiswa Pada Materi Barisan Bilangan Real dengan menerapkan metode inquiri. Data penelitian ini terdiri dari 2 macam yaitu data kualitatif dan data kuantitatif. Data kualitatif berupa data hasil observasi, sedangkan data kuantitatif adalah data hasil tes mahasiswa untuk pemahaman konsep pencemaran lingkungan.

Berdasarkan hasil penelitian yang telah dilakukan bahwa pada saat perlakuan awal pada silkus I hasil belajar mahasiswa yang tuntas secara indVidu 35 orang sementara mahasiswa yang tidak tuntas sebanyak 10 orang dengan presentase klasikalnya hanya mencapai 82,4 \%. Dengan demikian presentase ketuntasan klasikal ini dapat dikatakan masih rendah dari jumlah mahasiswa tuntas secara indVidu.

Selanjutnya pada siklus II diperoleh ketuntasan indVidu sebanyak 39 orang dari 45 orang mahasiswa yang mengikuti tes, sedangkan yang tidak tuntas sebanyak 6 orang dengan presentase ketuntasan klasikalnya 86,8 \%. Peningkatan yang dicapai pada siklus II merupakan hasil kerja keras dosen dalam upaya memperbaiki kesalahan-kesalahan yang dilakukan sebelumnya. Adapun kekurangan-kekurangan tersebut masih berkisar pada kurang mengoptimalkan peran dosen dalam membimbing dan mengarahkan mahasiswa serta menciptakan suasana belajar yang kondusif dan pengontrolan secara intensif terhadap kegiatan mahasiswa masih kurang. Untuk lebih jelas dapat dilihat pada tabel berikut: 
Tabel 1. Hasil Tes Pemahaman Konsep Siswa

\begin{tabular}{lcc}
\hline \multicolumn{1}{c}{ Tindakan } & Siklus I & Siklus II \\
\hline Jumlah Siswa & $(45$ siswa $)$ & $(45$ siswa $)$ \\
Tuntas & $(35$ siswa $)$ & $(39$ siswa $)$ \\
Belum Tuntas & $(10$ siswa $)$ & $(6$ siswa $)$ \\
Nilai rata-rata & 75,02 & 81,3 \\
Presentase ketuntasan & $82,4 \%$ & $86,8 \%$ \\
Kategori & Belum Tuntas & Tuntas \\
\hline
\end{tabular}

Berdasarkan hasil tes pada tiap siklus tentang ketuntasan belajar mahasiswa. Dalam penelitian ini untuk ketuntasan belajar mahasiswa secara indVidu maupun klasiklal digunakan pedoman ketuntasan mahasiswa, sebagai berikut:

\section{Ketuntasan Individu}

Seorang peserta didik dikatakan berhasil (mencapai ketuntasan) belajar bila telah mencapai taraf penguasaan minimal $70 \%$ atau dengan nilai 70. Bagi mahasiswa yang taraf penguasaannya kurang dari $70 \%$ diberikan remidi pada pokok bahasan yang belum dikuasai, sedangkan bagi mahasiswa yang telah mencapai penguasaan $70 \%$ atau lebih dapat melanjutkan kepokok bahasan berikutnya.

\section{Ketuntasan Klasikal}

Suatu kelas dikatakan telah berhasil (mencapai ketuntasan belajar) jika paling sedikit $85 \%$ data jumlah mahasiswa dalam kelas tersebut telah mencapai ketuntasan perorangan dengan ketentuan sebagai berikut:

a. Apabila sudah terdapat $85 \%$ dari jumlah mahasiswa keseluruhan dalam kelas yang mencapai tingkat ketuntasan belajar maka kelas tersebut dapat melanjutkan kegiatan pada satuan pembelajaran berikutnya.

b. Apabila jumlah mahasiswa yang mencapai tingkat ketuntasan belajar masih kurang dari 85\% maka: Mahaiswa yang taraf penguasaannya kurang dari 70\% harus diberi program perbaikan mengenai bagian-bagian pelajaran yang belum dikuasai. Mahaiswa yang telah mencapai taraf penguasaan $70 \%$ atau lebih dapat diberikan program pengayaan.

c. Untuk menentukan persentase dari pencapaian ketuntasan mahasiswa maupun kelas adalah sebagai berikut:

(1) Ketuntasan belajar secara individu 
Peserta dikatakan tuntas belajar secara indVidu bila memperoleh persentase daya serap individu $\geq 70 \%$

(2) Ketuntasan belajar secara klasikal.

$\%$ ketuntasan belajar $=\underline{\text { Jumlah } \text { mahasiswa yang tuntas }} \times 100 \%$

Jumlah seluruh mahasiswa

Peserta dikatakan tuntas belajar secara klasikal bila memperoleh persentase daya secara klasikal $\geq 85 \%$

Jika dalam suatu kelas ketuntasan mahasiswa lebih atau sama dengan $85 \%$ maka pembelajaran yang dilaksanakan dosen dapat dikatakan berhasil. Tetapi jika ketuntasan mahasiswa kurang dari $85 \%$ maka pembelajaran yang dilaksanakan dosen belum berhasil dan perlu diperhatikan mengenai metode dalam pembelajarannya.

Pada pembelajaran metode inquiri ini mahasiswa melakukan dan mencari sendiri jawaban dari pertanyaannya, kemudian dianalisis dan dipersiapkan alternatif jawaban dari permasalahan tersebut dan tidak mutlak mempunyai satu jawaban yang benar, tetapi mahasiswa dituntut pula untuk belajar secara kreatif. Disamping itu juga smahaiswa harus belajar dengan inisiatif sendiri dan hal ini dapat dilaksanakan secara individu maupun kelompok kecil yang dapat menimbulkan suasana belajar yang efektif dan kondusif.

Mengajarkan matematika tidaklah mudah, oleh karena itu tidak dibedakan antara matematika dan matematika sekolah. Maka dari itu perlu adanya pembelajaran khusus untuk meningkatkan kualitas belajar mengajar matematika, karena dalam tujuan pembelajaran matematika disebutkan bahwa tujuan yang hendak dicapai adalah menumbuhkan dan mengembangkan keterampilan berhitung (menggunakan bilangan) sebagai alat dalam kehidupan sehari-hari, menumbuhkan kemampuan mahasiswa yang dapat dialih gunakan melalui kegiatan matematika, dan memahami konsep matematika, menjelaskan keterkaitan antara konsep matematika dan mengaplikasikan konsep atau algoritma, secara luwes, akurat, efisien, dan tepat dalam pemecahan masalah.

Kemampuan mahasiswa yang diperoleh dari proses awal yaitu melalui berfikir dan mencari sendiri jawaban yang akhirnya dapat meningkatkan hasil belajar mahasiswa, khususnya dalam penelitian ini menunjukkan bahwa dengan penerapan metode inquiri dapat meningkatkan pemahaman konsep mahasiswa dengan melihat rangkaian kedua siklus yang telah diterapkan dengan refleksi yang terus dilakuakn menunjukkan peningkatan, sehingga 
dapat dikatakan bahwa keberhasilan yang telah dicapai mahasiswa dengan presentase ketuntasanya sebesar 86,8 \% menunjukan peningkatan kemampuan mahasiswa dalam proses belajar mengajar pada pokok Barisan bilangan Real.

Pembelajaran dengan menggunakan konsep berarti mahasiswa dibimbing memahami suatu bahasan melalui pemahaman konsep yang terkandung di dalamnya dengan beberapa langkah mahasiswa dibimbing untuk memahami konsep. Menggunaan metode inquiri ini mahasiswa dituntut untuk mencari sendiri jawaban dari rumusan problema yang ada. Proses inquiri adalah proses yang mengandung proses mental dengan demikian mahasiswa dihadapkan pada kondisi lingkungan yang ada dan sesuai dengan pokok bahasan yang diajarkan yaitu Barisan bilanagn Real, kemudian mahasiswa disuruh mencari sendiri kenapa pencemaran itu bisa terjadi. Penggunaan metode inquiri berarti membelajarkan mahasiswa untuk mengendalikan situasi yang dihadapi ketika berhubungan dengan lingkungan sekitar, dan mengaitkan lingkungan dalam suatu proses belajar mengajar.

Dilihat dari hasil penelitian diatas dapat diperoleh gambaran bahwa penerapan metode inquiri dapat membantu mahasiswa untuk memahami konsep Barisan bilanagn Real dan secara umum mahasiswa merasa senang dan termotivasi saat pembelajaran.

\section{KESIMPULAN}

Atas dasar pembahasan hasil penelitian yang telah dilakukan, dapat disimpulkan bahwa pembelajaran menggunakan metode inquiri dapat meningkatkan pemahaman konsep mahasiswa pada materi Barisan bilangan Real mahasiswa semester V A-B . Hal ini terbukti dengan tingkat pemahaman pada siklus I dan pada siklus II untuk ketuntasan klaksikal pada siklus I (82,4 \% dengan kualifikasi Baik) dan pada siklus II sebesar (86,8 \% dengan kualifikasi Amat baik).

Ada peningkatan hasil belajar mahasiswa dengan cara belajar dengan menggunakan metode inquiri. Hal ini menunjukkan bahwa jika cara belajar mahasiswa baik dan benar maka berhubungan dengan hasil belar mahasiswa. Hal ini dapat dilihat dari peningkatan pemahaman setiap siklus yaitu pada siklus I mahasiswa tuntas belajar persentasi ketuntasan 82,4\% dan pada siklus II mahasiswa mencapai ketuntasan dengan persentasi 86,8 \%. 


\section{REKOMENDASI}

Selanjutnya, berdasarkan hasil penelitian dengan penerapan model problem posing ini, peneliti merekomendasikan dalam penerapan metode Inquiri untuk meningkatkan hasil belajar siswa dalam penelitian ini masih terbatas, untuk itu perlu adanya penelitian lanjutan dengan masalah yang lain.

\section{UCAPAN TERIMAKASIH}

Puji syukur penulis panjatkan kehadirat Allah SWT yang telah mencurahkan nikmat, diantaranya nikmat sehat dan kesempatan. Berkat nikmat sehat dan kesempatan, penulis mampu berpikir dan berbuat dalam menyelesaikan penelitian hingga pembuatan laporan hasil penelitian dengan judul "Penerapan Metode Inquiri Dalam Meningkatkan Konsep Berpikir Mahasiswa Pada Materi Barisan Bilangan Real".

\section{REFERENSI}

Arikunto, S. (1993). Prosedur Penelitian Suatu Pendekatan Praktik. Bandung: Rineka Cipta.

Chabib, T. (2003). Teknik Evaluasi Pendidikan. Jakarta: RajaGrafindo Persada.

Joko, S. (2009). "Metode Pembelajaran Inquiry", dalam http://www.erlangga.co.id com, diambil pada tanggal 10 Februari 2009, pukul 09.10 WITA.

Margono. (2005). Metodelogi Penelitian Pendidikan. Jakarta: Rineka Cipta.

Moedjiono \& Dimyanti. (2006). Belajar dan Pembelajaran. Jakarta: Rineka Cipta.

Muhibbin, S. (2006). Psikologi Belajar. Jakarta: RajaGrafindo Persada.

Nasution. (2004). Metode Research (Penelitian ILmiah). Jakarta: Bumi Aksara.

Rustam \& Mundilarto. (2004). Penelitian Tindakan Kelas. Direktorat Pembina Pendidikan Tenaga Kependidikan dan Ketenakaan Perguruan Tinggi Direktoral Jenderal Pendidikan Tinggi Depertemen Pendidikan Nasional.

Sagala, S. (2006). Konsep Dan Makna Pembelajaran Untuk Membantu Memecahkan Problemátika Belajar dan Mengajar. Bandung: Alfabeta.

Sanjaya, W. (2007). Strategi Pembelajaran Berorientasi stándar Proses Pendidikan. Jakarta: Kencana.

Subana dkk. (2005). Statistik Pendidikan. Bandung: Pustaka Setia.

Sudjana, N. (2004). Dasar-Dasar Proses Belajar Mengajar. Bandung: Sinar Baru Algensindo. 
53 SUPERMAT, Volume 2, No. 1, April 2018, hal. 44-53

Riyanto, Y. (2001). Metodelogi Penelitian Pendidikan. Surabaya: SIC.

Undang-undang Sisidiknas No. 20 Tahun 2003.

Yusuf. (2008). Power Point Ketuntasan Belajar. Mataram: IAIN Mataram. 